\title{
ANALYTICAL REFLECTION OF BALANCE OF PAYMENT CONCERNING ECONOMY OF BANGLADESH
}

\author{
NARGIS SULTANA \\ Lecturer, Department of Finance \& Banking, Comilla University, Bangladesh
}

\begin{abstract}
A country's balance of payment articulates whether that country hoards abundant to recompense for its imports. It harmoniously divulges whether the country harvests enough economic yields to pay for its advancement. As a developing country, it cannot be supposed that, the performances of Bangladesh in Balance of Payments are good-looking. The objective of this coursework is to develop some ideas regarding the recent trends of balance of payments of our country. The coursework has employed secondary data to validate the conclusions. The conclusion is that Bangladesh should overwhelmed its undesirable trade balances through swelling its export earnings and reducing the dependency on imports. There are roughly potential sources which can help to facilitate exports. Concentration should be distracted from import to the development of domestic industry by utilizing resources and providing eminence products. The positive thing is that still Bangladesh has a great prospect in Balance of Payment.

KEYWORDS: Exports, Imports, Trade Balance, Growth Rate, Monetary Transactions \& Economic Yield
\end{abstract}

Received: Jan 27, 2018; Accepted: Feb 16 2018; Published: Mar 13, 2018; Paper Id.: IJECRAPR20183

\section{INTRODUCTION}

Bangladesh is an evolving economy in the world. The performance of its BOP and the improvement of its economy are linked to each other. The main structures and paleness of our BOP are that it is import -dominated. The growth of imports is significantly higher than that of exports. Historically, Bangladesh faces a deficit in trade balance. In Fiscal Year (FY) 2016-17, export earnings were \$34019 million and it was 1.73\% higher than that of the previous FY i.e. 2015-16 which was \$33441 million. On the other hand, import payments were \$43491 which was $9 \%$ higher than that of the previous year which was $\$ 39901$ million. From this scenario, it is clear that there is a trade deficit as import payments are higher than export earnings. Although exports have been increased $1.73 \%$, imports have been increased 9\% which is significantly higher than exports. Higher import is the main reason for the deficit in trade balance every year. If we can reduce the import dependency or increase the level of export, then it will help reduce the pressure on of our BOP, generated from import dependence. As our growth of export is lower than that of import, most of the time our trades balance is negative. The value of service imports usually exceeds the value of service exports that our outflow is greater than inflows. The historical data indicates that our payments are fluctuating but receipts are increasing gradually that indicates our service providing capacity is improving. In FY 2016-2017, Service receipt increases $2.78 \%$ than the previous year and service payment increased by $10.82 \%$. The highest amount of receipts occurred in the FY 2016-17 and the amount is US\$3621.

\section{OBJECTIVES OF THE STUDY}

- To identify the reasons of backwardness in Balance of Payment along with recommendations. 
- $\quad$ To suggest some measures so that Balance of Payment can contribute more to the economy.

- $\quad$ To show that focus should be diverted form import orientation to export orientation.

- $\quad$ To identify the causes of disequilibrium hindering the progress of economy along with corrective measures.

\section{METHODOLOGY OF THE STUDY}

In this study, I have shown the last five years (2012-2017) trend of Bangladesh's balance of payments. Each account is represented graphically along with historical data of Statistics Department of Bangladesh Bank from FY 201213 to 2016-17. This study is conducted by using trend analysis. The trend analysis is used to show the changes from year to year. The historical trend analysis and recent data (secondary) are provided to support the findings. I also have given some recommendations thereby we can accelerate our growth rate.

\section{LITERATURE REVIEW}

There exists a positive relationship between export and economic growth. Mushfica Akhter (2015) said the impact of export on economic growth found as positive and an opposite scenario is found in the case of import.

As a developing country, Bangladesh should form such policies which facilitate export and restrict import. M. S. Rahman Chowdhury (2013) revealed that Bangladesh should relax restrictions on imports more slowly than barriers to exports.

Trade policy has a relationship with Balance of Payment. Dr. Md. Moniruzzaman (2010) suggested that the policy makers should pay proper attention on the export sector in designing trade policy of Bangladesh. Mohammad A. Ashraf and Hasanur R. Joarder (2009) recommended that budget of government should be well-adjusted and the import segment ought to be restricted to cuddle the import expenditure.

Bangladesh should develop an export-led strategy. Reza (1981) analyses the chronic trade deficit of Bangladesh arguing that the export base and export earnings are persistently very low over a long period of time. He finds out the performance of the export sub - sector is very poor because of the heavy concentration on few traditional items.

Ahmed (2001) finds that both in aggregate and commodity level the import is generally less sensitive to import price, whereas export both at an aggregate and commodity level are sensitive to real exchange rate and relative prices.

Mahmood (1982) argues that a country like Bangladesh can achieve high standards of living only through industrialization and expansion of trade in manufacturing. But Roy (1991) finds that the export performance of Bangladesh is associated with greater commodity diversification of exports. A. R. Bhuyan (1982) examines the prospect of nontraditional exports focusing on the imports of machinery and industrial raw materials.

Several researchers have conducted research regarding Balance of Payment indicating export-led strategy to the development of non-traditional items. This study is conducted to identify the reasons of backwardness (or deficit or disequilibrium) in Balance of Payment analyzing the previous 5 (five) years records. This study will add a value by providing corrective measures as recommendations to improve the current situation of Balance of Payment to facility a better role in the economy of Bangladesh. 


\section{COMPONENTS OF BALANCE OF PAYMENTS}

Current Account Balance+Financial Account Balance+Capital Account Balance $=0$

Fundamental balance of payments identity

An implication of the double-entry book-keeping methodology. Example: An export transaction is recorded in 2 countries (once with plus export and once with a minus import)

So, there are three components of balance of payments and they are as follows;

Current Account: Trade balance and income from abroad (Exports-Imports +International income receiptspayments to foreigners, e.g. Japanese TV imported)

Financial Account: Sales of assets to foreigners-Purchases of assets located abroad (e.g. Purchasing a residence abroad)

Capital Account: Capital transfers (e.g. Charity gift)

\section{Current Account}

The current account measures a country's financial position in the world, casing all dealings that take place between resident and non-resident individuals. A positive balance-a current account surplus displays an economy is receiving more from its global export transactions than outgoings overseas from import dealings with other economies and as a result a net creditor concerning the rest of the domain. A negative balance- a current account deficit displays an economy is receiving less from its global export transactions than outgoings overseas from import dealings with other economies. A nation is more expected to have a shortfall in its current account the sophisticated its price level, the sophisticated its gross national product, the sophisticated its interest rates, the lesser its barriers to imports, and the more striking its investment prospects - all compared with conditions in other countries and the sophisticated its exchange rate. The effects of a change in one of these factors on the current account balance cannot be predicted without considering the effect on the other causal factors. Added definitely the four core components of the current account are well-defined as follows.

$\begin{array}{ll}\text { - } & \text { Trade balance } \\ \text { - } & \text { Services } \\ \text { - } & \text { Primary income } \\ & \text { Secondary income }\end{array}$


BANGLADESH BALANCE OF PAYMENTS (2012/2013- 2016/2017

(In Million US\$)

Table 1: Last Five Years Balance of Payments at a Glance

\begin{tabular}{|c|c|c|c|c|c|c|c|}
\hline ITEM & $\begin{array}{l}2012- \\
2013\end{array}$ & $\begin{array}{l}2013- \\
2014\end{array}$ & $\begin{array}{l}2014- \\
2015\end{array}$ & $\begin{array}{l}2015- \\
2016\end{array}$ & $\begin{array}{c}\text { CHANGES } \\
04 \text { OVER } \\
03(\%)\end{array}$ & $\begin{array}{l}2016- \\
2017\end{array}$ & $\begin{array}{c}\text { CHANGES } \\
\text { 05 OVER } \\
04(\%)\end{array}$ \\
\hline & 01 & 02 & 03 & 04 & & 05 & \\
\hline Trade Balance & -7010 & -6806 & -9917 & -6460 & & -9472 & \\
\hline Exports f.o.b. (including EPZ) & 26566 & 29765 & 30768 & 33441 & & 34019 & \\
\hline Import f.o.b (including EPZ) & 33576 & 36571 & 40685 & 39901 & & 43491 & \\
\hline Services & -3162 & -4189 & -4628 & -2708 & & -3482 & \\
\hline Receipts & 2830 & 3065 & 3017 & 3523 & & 3621 & \\
\hline Payments & 5992 & 7254 & 7645 & 6231 & & 6905 & \\
\hline Primary Income & -2369 & -2370 & -2995 & -1915 & & -2007 & \\
\hline Receipts & 120 & 171 & 74 & 74 & & 82 & \\
\hline Payments & 2489 & 2541 & 3069 & 1989 & & 2089 & 1.73 \\
\hline Secondary Income & 14928 & 14912 & 15894 & 15345 & & 13283 & 9 \\
\hline Official & 97 & 79 & 74 & 67 & $\begin{array}{r}8.69 \\
1.03\end{array}$ & 44 & \\
\hline Private & 14831 & 14833 & 15820 & 15278 & -1.93 & 13239 & 2.78 \\
\hline Of which workers' remittances & 14338 & 14115 & 15170 & 14717 & & 12591 & 10.82 \\
\hline Current Account Balance & $\underline{2387}$ & $\underline{1547}$ & $\underline{-1646}$ & $\underline{4262}$ & $\begin{array}{c}16.77 \\
-18.50\end{array}$ & -1480 & 10.81 \\
\hline Capital Account & 629 & 644 & 483 & 464 & & 314 & 5.03 \\
\hline Capital transfers & 629 & 644 & 483 & 464 & $\begin{array}{c}0 \\
3520\end{array}$ & 314 & \\
\hline Financial Account & 2770 & 3121 & 5308 & 944 & -35.20 & 4179 & -34.33 \\
\hline Foreign Direct Investment & 1726 & 1550 & 1830 & 2502 & & 2985 & -13.35 \\
\hline Portfolio Investment & 368 & 825 & 618 & 139 & -9.46 & 458 & -14.45 \\
\hline Other Investment & 676 & 746 & 2860 & -480 & $\begin{array}{r}-3.43 \\
2.00\end{array}$ & 2015 & \\
\hline Medium \& Long-term (MLT)loan & 2085 & 2277 & 2472 & 3033 & -2.99 & 3174 & \\
\hline MLT amortization payments & -906 & -1018 & 910 & 849 & & 895 & \\
\hline Other long-term loans (net) & -150 & 418 & -33 & -110 & & -193 & -32.33 \\
\hline Other short-term capital (net) & 193 & 355 & -161 & -435 & & 992 & \\
\hline Other assets & 0 & 0 & 0 & 0 & -3.93 & 0 & 19.3 \\
\hline Trade credit (net) & -250 & -1045 & 690 & -2101 & 36.72 & -1185 & \\
\hline Commercial Bank & 90 & -241 & 802 & -18 & & 122 & 4.65 \\
\hline Assets & -396 & -898 & 86 & 347 & & 178 & 5.42 \\
\hline Liabilities & 486 & 657 & 888 & 329 & $\begin{array}{c}22.69 \\
6.70\end{array}$ & 300 & \\
\hline Errors and Omissions & -659 & 171 & 228 & -634 & & 156 & \\
\hline OVERALL BALANCE & $\underline{5128}$ & $\underline{5483}$ & $\underline{4373}$ & $\underline{5036}$ & & $\underline{3169}$ & \\
\hline Reserve Assets & -5128 & -5483 & -4373 & -5036 & & -3169 & \\
\hline Bangladesh Bank & -5128 & -5483 & -4373 & 5036 & & -3169 & \\
\hline Assets & -5196 & -5933 & 4249 & 5322 & & 3208 & \\
\hline Liabilities & 68 & 450 & -124 & 286 & & 39 & \\
\hline
\end{tabular}

Source: Statistics Department, Bangladesh Bank

\section{Trade Balance}

Merchandise exports and imports represent tangible products, such as computers and clothing. Exports and imports of merchandises are logged on a so-called free-on-board (FOB) assessment. Historically, the import bills were higher in comparison with export earnings due to which Bangladesh had to face a persistent trade deficit over the years. If 
the export earnings are higher than the import bills then it is known as Trade Surplus and if the export earnings are lower than the import bills then it is known as the Trade Deficit.

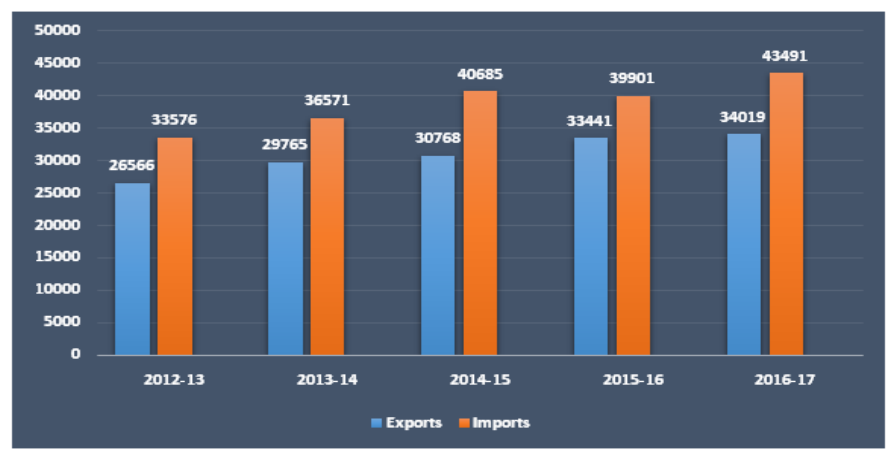

Source: Statistics Department, Bangladesh Bank

Figure 1: The Last Five Years' Trade Balances (In Million US\$)

In Fiscal Year (FY) 2016-17 export earnings were $\$ 34019$ million and it was $1.73 \%$ higher than that of the previous FY i.e. $2015-16$ which was $\$ 33441$ million. On the other hand, import payments were $\$ 43491$ which was $9 \%$ higher than that of the previous year which was $\$ 39901$ million. From this scenario, it is clear that there is a trade deficit as import payments are higher than export earnings. Both exports and imports were higher in the FY 2016-17. But the deficit balance in trade has been increased than the previous FY due to higher import payments.

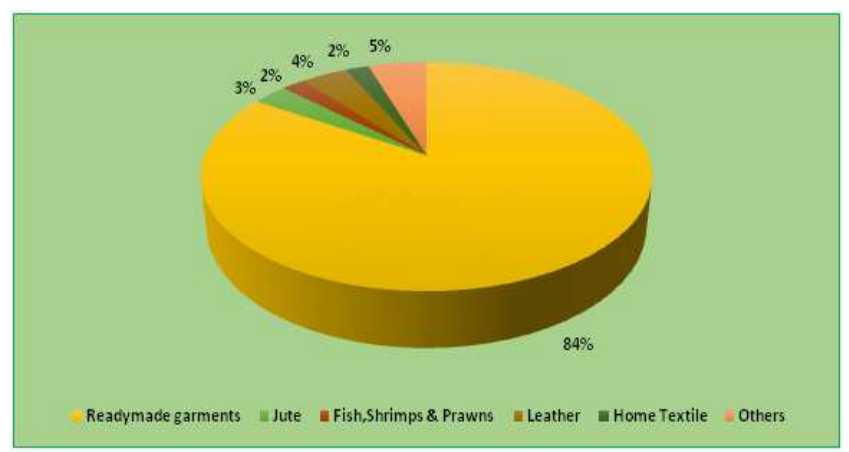

Source: Bangladesh Bank, 2016

Figure 2: Commodity-Wise Export

The readymade garments sector contributes the lion share of our export earnings. From the above figure it is seen that its contribution is $84 \%$. Other sectors like jute, fish \& shrimp, leather and other sectors are also important part of our export business since the economy of Bangladesh is not reliant on on any single sector for acquiring its target growth rate.

\section{Services}

Service exports and imports represent tourism and other services such as legal, insurance and consulting services provided for customers based in other countries. Service exports by the Bangladesh result in an inflow of funds to the Bangladesh, while service imports by the Bangladesh result in an outflow of funds. 


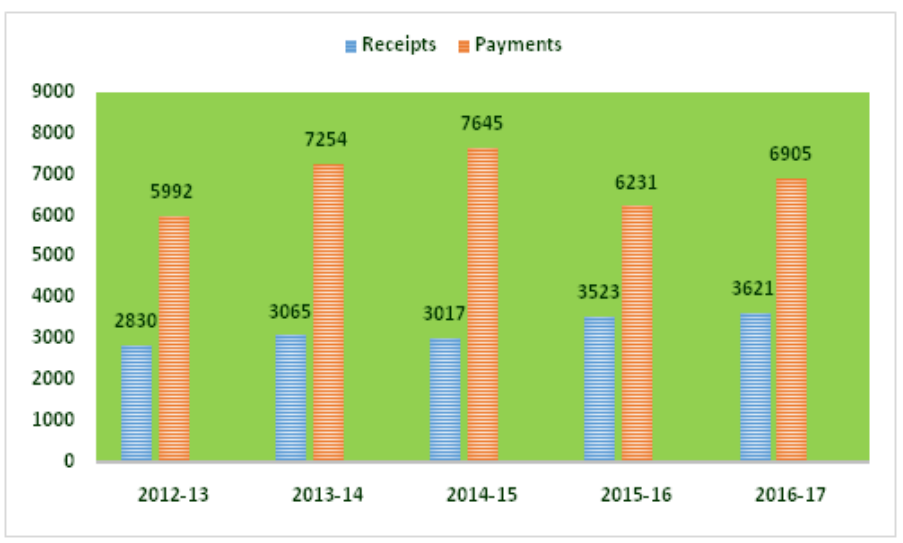

Source: Statistics Department, Bangladesh Bank

Figure 3: The Last Five Years' Trend of Services (In Million US\$)

The value of service imports usually exceeds the value of service exports that our outflow is greater than inflows. In the graph we can see that, our payments are fluctuating but receipts are increasing gradually that indicates our service providing capacity is improving. In FY 2016-2017, Service receipt increases 2.78\% than the previous year. On the otherhand, in the same FY service payment increased by $10.82 \%$. The highest amount of receipts occurred in the FY 2016-17 and the amount is US\$3621.

\section{Primary Income}

Primary income includes basically three types of dealings and they are-

Compensation of employees remunerated to non-resident workers or received from non-resident employers,

Investment income and

Supplementary primary income (taxes on manufacture and on imports, subsidies and rent).

All investment income modules include the income on equity and investment fund shares (divided between disseminated and accrued income) and interest from investment in debt securities, deposits or loans, and investment withdrawals from income of quasi-corporations.

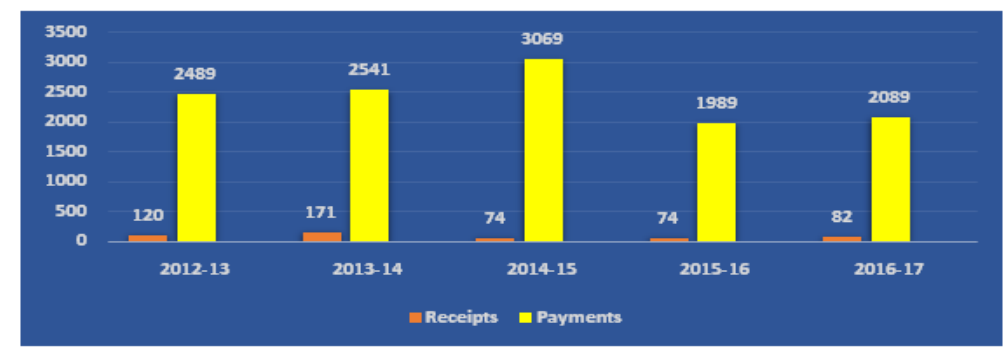

Source: Statistics Department, Bangladesh Bank

Figure 4: The Last Five Years' Trend of Primary income (In million US\$)

In FY 2016-17, the receipts under primary income were US\$ 82million which was 10.81\% higher than that of the previous year. In FY 2015-16, receipts were US \$ 74million which is equal to the previous year's receipts. Hence there is no percentage increase. In FY 2016-17, payments were US\$2089million which was 5.03\% higher than that of the previous FY which was US\$ 1989million. Although overall payments have been decreased than the FY 2014-15, but payments 
against receipts are higher. That is why primary income shows a deficit trend over the years. The highest deficit occurred in FY 2014-15 and the lowest in FY 2015-16.

\section{Secondary Income}

\section{Secondary income includes}

Common government current transfers, for instance expenditures of current taxes on income and wealth,

Social charities and benefits, transfers related to international assistance, and

Current allocations connected to financial and non-financial corporations, households, or non-profit officialdoms.

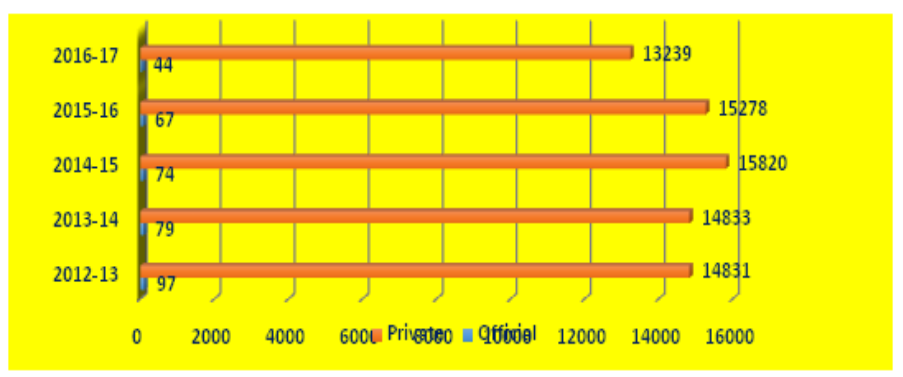

Source: Statistics Department, Bangladesh Bank

Figure 5: The Last Five Years' Trend of Secondary Income (In million US\$)

In FY 2016-17, the balance of secondary income was US\$13283million and in FY 2015-16 the balance was US $\$ 153345$ million. So there is deficit balance in the last FY. The highest amount of secondary income was US\$ 15894million in FY 2014-15 but the amount was decreased in FY 2015-16. And the lowest amount of secondary income was US\$13283 in FY 2016-17. After the end of the year 2014-15, the secondary income shows a declining trend.

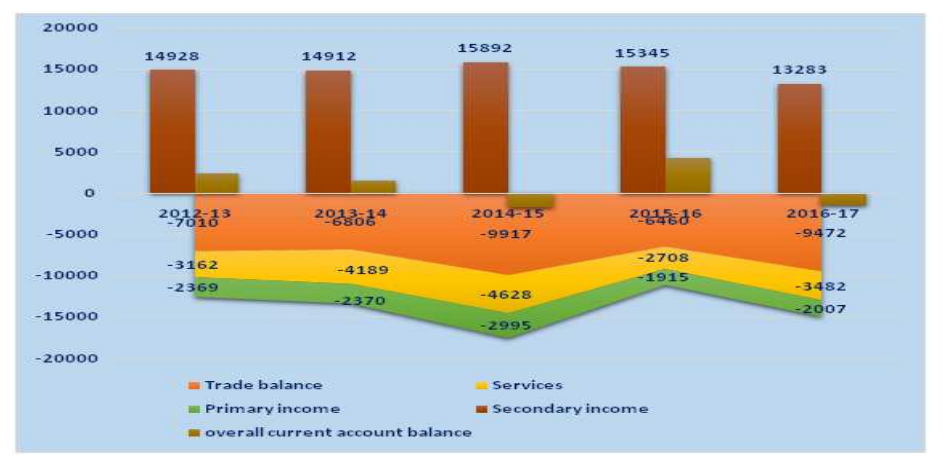

Source: Statistics Department, Bangladesh Bank

Figure 6: The Last Five Years' Trend of Current Account Balance (In million US\$)

The current account shows a deficit balance in the last FY i,e 2016-17. Although in FY 2015-16, there was a surplus of US\$ 4262 million. The last year's deficit situation occurred due to high imports for construction purposes and at the same time low export earnings. The natural calamities that Bangladesh faces during the last several months are also factors that contribute to decreased export earnings. All of the components of current account show deficit balance except secondary income during the last five years. 


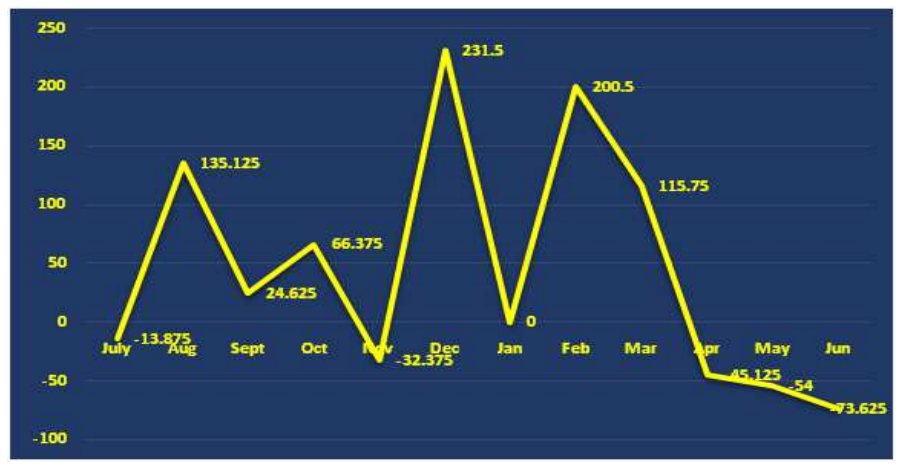

Source: tradingeconomics.com, Bangladesh Bank

Figure 7: Monthly Scenario of Current Account (In million US\$)

Last 12 months scenario shows an unstable trend of current account balance. There is a continuous negative balance from April to June. The economy of Bangladesh is not able to earn enough money that causes a positive current account balance. The amount shown in Jun (BDT -589) was all time higher deficit balance among those twelve months.

\section{Capital Account}

Capital account can be regarded as one of the crucialmodules of balance of payments of a nation. It gives a summary of the capital expenditure and income for a country. The capital account comprises the value of economic assets transferred crossways country boundaries by publics who move to a diverse country. It also includes the worth of nonproduced nonfinancial properties that are transmitted across country boundaries, such as patents and trademarks. The capital account stuffs are comparatively minor associated to the financial account stuffs.

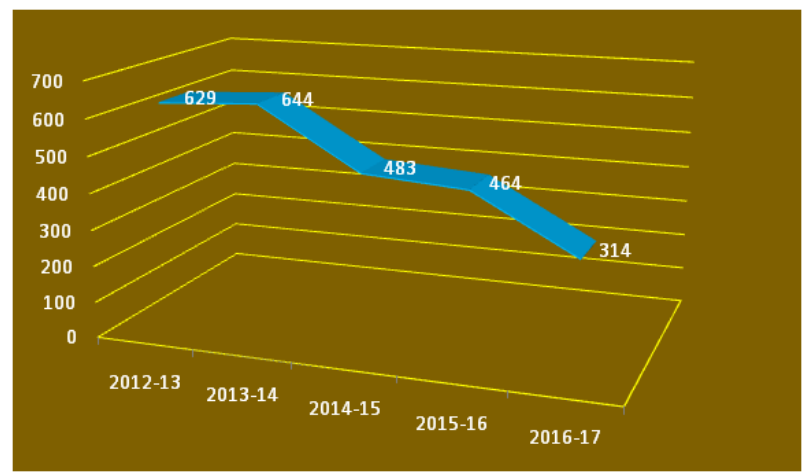

Source: Statistics Department, Bangladesh Bank

Figure 8: The Last Five Years' Trend of Capital Account (In million US\$)

In FY 2013-2014 Capital transfer was in surplus (USD644million) which was largest of the five years capital Account trend. In FY 2016-2017 capital transfer is US\$314 million, which is lowest among the five year balances. The capital account shows a decreasing trend since FY 2013-2014 which indicates that the capital inflows are lower than the capital outflows.

\section{Financial Account}

A financial account concealments claims on or liabilities to non-residents, specifically with regard to financial assets. Three types of investment (Direct Foreign Investment or DFI, Portfolio Investment and Other Capital Venture) amalgamate the financial account laterally with (net) financial spin-offs and reserve assets. Assets and liabilities are 
understood as net values (net attainment of assets, net incurrence of liabilities). Consequently, the net financial account is understood as net loaning to the respite of the world when positive, and net borrowing starting the respite of the world while negative.

\section{Direct Foreign Investments}

Direct foreign investment signifies the venture in fixed assets in foreign nations that can be used to conduct commercial operations. Instances of direct foreign investment comprise a firm's attainment of a foreign company, its building of a new manufacturing plant, or its enlargement of anprevailing plant in a foreign country.

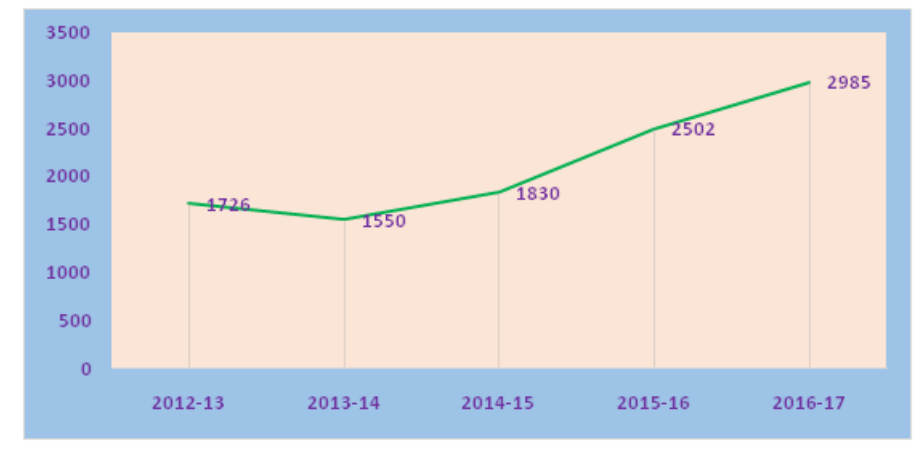

Source: Statistics Department, Bangladesh Bank

Figure 9: The Last Five Years' Trend of Direct Foreign Investment (In million US\$)

The graph shows an increasing trend of DFI. In FY 2013-2014 it was US\$ 1550mn which is lowest among the five year trends. But now it is US\$2985mn which indicates gradually we become more interested in foreign investment. One of the major disadvantages of DFI is, it decreases employment opportunities in domestic countries. In DFI a country invests in foreign country other than home country that reduces the opportunity of industrialization thereby unemployment increases but its playing ansignificant role in the economy.

\section{Portfolio Investment}

Portfolio investment signifies transactions connecting long- term financial assets (such as stocks and bonds) amid countries that do not distress the transfer of control. The conformation of investments in a portfolio hinge on a numeralaspects. Some of the most significantcomprise the amount invested, investment horizon and finally investor's risk tolerance.

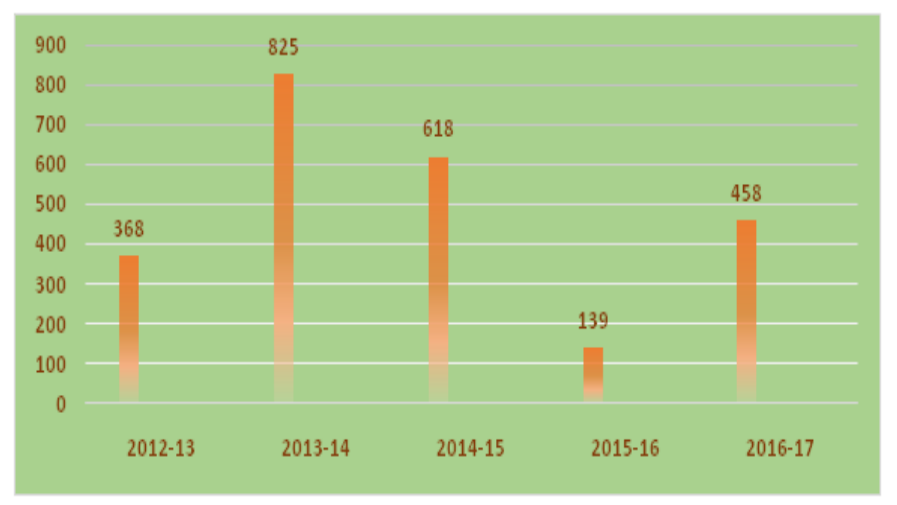

Source: Statistics Department, Bangladesh Bank

Figure 10: The Last Five Years' Trend of Portfolio Investment (In Million US\$) 
The five year trends of portfolio investment shows a fluctuating situation. In FY 2013-14 portfolio investments was US\$ 825 million which was largest among five year trends. After FY 2013-14 it shows a decreasing trends in investment till FY 2015-16. But in FY 2016-17 portfolio investments is US \$458mn which is larger than previous year.

\section{Other Capital Investment}

A third constituent of the financial account comprises of other capital investment, which signifies transaction connecting short-term financial assets (such as money market securities) amid countries. In broad, direct foreign investment trials the enlargement of firms' foreign operations, whereas portfolio investment and other capital investment grade the net flow of funds owing to financial asset transactions amid individual or official investors.

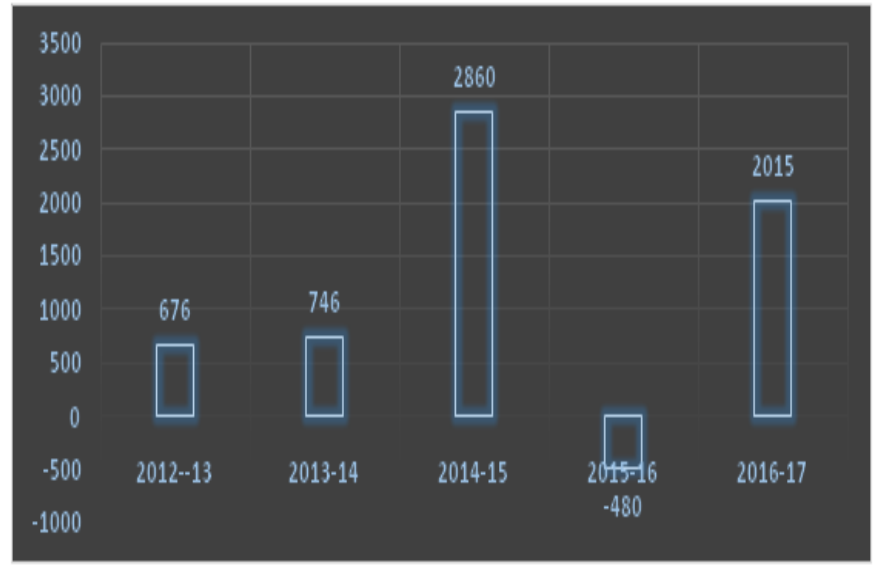

Source: Statistics Department, Bangladesh Bank

Figure 11: The Last Five Years' Trend of Other Investments (In million US\$)

Other investments balance shows an unstable trend. The lowest amount of investments was in the FY 2015016, a negative balance of USD $\$ 480$ million. The highest amount of other investments was in the FY 2014-15. After the end of FY 2015-16, the balance is increasing.

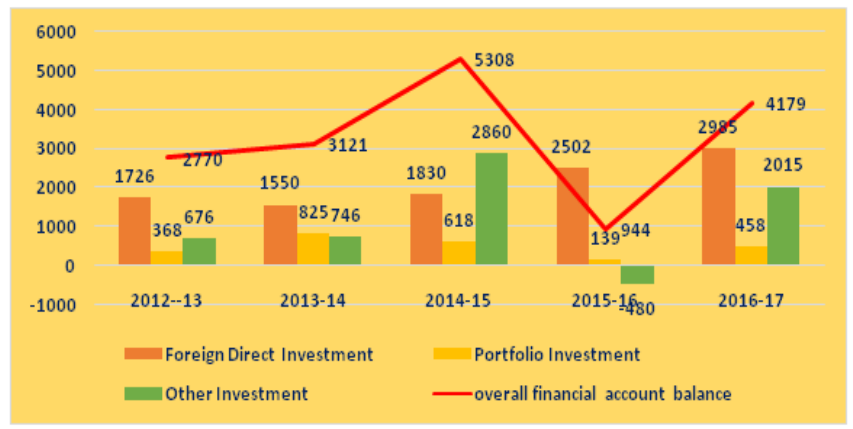

Source: Statistics Department, Bangladesh Bank

Figure 12: The Last Five Years' Trend of Financial Account (In million US\$)

\section{BREAKDOWN OF OVERALL BALANCE}

From the above study it is clear that the balance of payment (BOP) of Bangladesh is in surplus during the last FY but the amount has been reduced than the previous year. Although current account balance is not stable, capital and financial account balance are positive. This situation will be better if we can expand our import volumes and reduce our 
dependency on imports. The Bangladesh Bank (BB) data exhibited the country's overall balance of payments (BOP) excess was 3,169 million U.S. dollars in the fiscal year 2016-17 alongside 5,036 million U.S. dollars in the fiscal year 2015-16 (July 2015-June 2016). For the decrease in remittances, the current account balance also exhibited a deficit of 1,480 million U.S. dollars in the fiscal year 2016-17 against the surplus of 4,262 million U.S. dollars in the previous fiscal year. Conferring to the data, the flow of inner remittances in the fiscal year 2016-17 fell about 14.47 percent to $12,769.45$ million dollars.

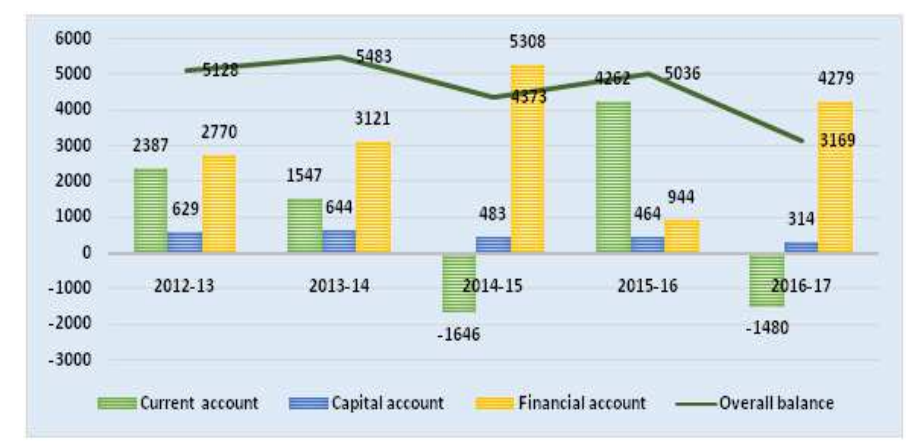

\section{Source: Statistics Department, Bangladesh Bank}

Figure 13: Last Five Years' Overall Balance (In million US\$)

In the FY 2016-17 and 2014-15 current account balance was deficit due to higher negative trade balance. The trade balance is negative because our import payments are higher than the export receipts. Both services and primary income was in deficit $i$, e our payments are higher than receipts. The last three months current account balance also shows a declining trend. There are some factors which are responsible for higher imports, such as flood, excessive rainfall; shelter of refugees etc. It isn't possible to trade-off between imports and exports. Thai is why the trade balance shows a deficit balance in almost every year which is the main reason for deficit current account balance.

The capital account shows a declining trend because of higher purchase of capital assets such as Submarine from China, Boeing plane from Russia. There was a decline of 32.33\% in the FY 2016-17 than the previous year. After the end of the FY 2013-14, capital outflows always exceeded the capital inflows. Bangladesh is dependent on foreign countries' imported equipment for establishing industrial enterprises. Although we are going to be digitalized day by day, there are various sectors where special focus should be given for the welfare of the people.

At present, the financial account balance shows an increasing trend. Direct foreign investment is gradually increasing since FY 2013-14. Foreign investors are now willing to invest in Bangladesh because it is possible to earn a good return that is beneficial for the foreign investors as well as Bangladeshi people. The more the direct foreign investment, the more expansions of industrial sectors are possible. Portfolio investment shows an unstable trend. The lowest portfolio investment was in the FY 2015-016. The political instability that was existed after the 10th national parliamentary election is the reason for lower amount of portfolio investment. Other investments were also negative in this FY.

Now the Balance of Payments of Bangladesh as per FY 2016-17 is US\$ 3169 million. It indicated a decline compared to the previous year which was US\$ 5036 million. Although capital and financial account is positive in FY 2016-17, but a negative current account balance lowers the overall balance of payments. If the current account balance was positive, the last year's balance of payments would be higher than that of the previous year. The BOP of 2014-15 was also 
lower than that of the previous FY due to negative current account balance. In order to foster the volume of overall balance of payments, focus should be given in all respects.

\section{ANALYSIS INDICATING THE REASONS BEHIND DISEQUILIBRIUM IN BOP}

A Numerous factors which cause volatility in the BOP indicating either surplus or deficit

\section{Economic Factors}

Unevenness between exports and imports,

Outsized scale development outlay which grounds large imports,

High local prices which pointer to imports,

Cyclical fluctuations in general business activity,

New springs of supply and new alternates.

\section{Political Factors}

Political unpredictability and turbulences cause large capital discharges and impede Inflows of foreign capital.

\section{Social Factors}

Deviations in fashions, tastes and preferences of the people bring uncertainty in BOP by swaying imports and exports;

High population progression in poor countries unpleasantly affects their BOP because itescalations the needs of the countries for imports and decreases their capability to export.

\section{Temporary Changes (or Disequilibrium)}

There may be a temporary disequilibrium caused by random variations in trade, seasonal fluctuations, the effects of weather on agricultural production, etc. Deficits or surpluses arising from such temporary causes are expected to correct themselves within a short time.

\section{Fundamental Disequilibrium}

Fundamental disequilibrium refers to a persistent and long-run BOP disequilibrium of a country. It is a chronic BOP deficit, according to IMF. It is caused by such dynamic factors as:

The Changes in consumer tastes within the country or abroad which reduce the country's exports and increase its imports.

Continuous fall in the country's foreign exchange reserves due to supply in-elasticity of exports and excessive demand for foreign goods and services.

Excessive capital outflows due to massive imports of capital goods, raw materials, essential consumer goods, technology and external indebtedness.

Low competitive strength in world markets which adversely affects exports.

Inflationary pressures within the economy which make exports dearer. 


\section{Structural Variations (or Disequilibrium)}

Structural variations bring about disequilibrium in BOP over the long run. They mayconsequence from the following factors:

Technological variations in methods of production of products in domestic industries or in the industries of other countries. They lead to variations in costs, prices and quality of products.

Import constraints of all kinds bring about disequilibrium in BOP.

Deficit in BOP also arises when a country agonizes from deficiency of resources which it is required to import from other countries.

Instability in BOP may also be caused by changes in the supply or direction of long-term capital flows. More and regular flow of long-term capital may front-runner to BOP surplus, while an irregular and short supply of capital brings BOP deficit.

\section{Changes in Exchange Rates}

Variations in foreign exchange rate in the form of overvaluation or undervaluation of foreign currency lead to BOP volatility.

\section{Cyclical Fluctuations (or Disequilibrium)}

When there is melancholy in a country, volumes of both exports and imports fall drastically in relation to other countries. But the fall in exports may be more than that of imports due to decay in domestic production. Therefore, there is an adverse BOP situation.

When there is flourishing in a country in relation to other countries, both exports and imports may increase. But there can be either a surplus or deficit in BOP situation dependentupon whether the country exports more than imports or imports more than exports. In both the cases, there will be disequilibrium in BOP.

\section{Changes in National Income}

If the national income of a country upsurges, it will lead to an intensification in imports thereby making a shortfall in its balance of payments, other things lingering the same.

If the country is previously at full employment level, an intensification in income will lead to inflationary rise in prices which may upsurge its imports and thus bring volatility in the balance of payments.

\section{Price Changes}

Inflation or deflation is another cause of instability in the balance of payments. If there is inflation in the country, prices of exports upsurge. As a result, exports fall. At the same time, the demand for imports upsurge. Thus increase in export prices leading to decline in exports and rise in imports results in adverse balance of payments.

\section{Stage of Economic Development}

A country's balance of payments also be contingent on its stage of economic progress. As Bangladesh is developing it will have a shortfall in its balance of payments as it imports raw materials, machinery, capital equipment, and services related with the development process and exports primary products. The country has to pay extra for costly 
imports and gets less for its cheap exports. This leads to volatility in its balance of payments.

\section{Capital Movements}

Borrowings and lending or movements of capital by countries also result in imbalance in BOP. A country which gives loans and grants on a large scale to other countries has a deficit in its BOP on capital account. If it is also importing more, as is the case with the USA, it will have chronic deficit. On the other hand, a developing country like Bangladesh borrowing large funds from other countries and international institutions may have a favorable BOP. But such a possibility is remote because these countries usually import huge quantity of food, raw materials, capital goods, etc. and export primary products. Such borrowings simply help in reducing BOP deficit.

\section{Secular or Long-Run Disequilibrium}

Secular (long-run) disequilibrium in balance of payments occur because of long-run and deep-seated changes in an economy as it develops from one stage of growth to another. Balance of payments in current account follows a varying pattern from one stage to another. In the initial stages of development, domestic investment exceeds domestic savings and imports exceed exports. Disequilibrium arises due to lack of sufficient funds available to finance the import surplus, or the import surplus is not covered by available capital from abroad.

\section{Technological Flux}

Technological volatility in the balance of payments is triggered by various technological variations. Technological variationsinclude inventions or innovations of new goods or new techniques of production. These technological variations affect the demand for goods and productive factors which in turn stimulus the various items in the balance of payments. Each technological variation implies a new comparative advantage to which a country corrects to. The innovation leads to amplified exports if it is a new good and export-biased innovation. The innova-tion may lead to decay in imports if it is import-biased andthis will makedisequilibrium. A new evenness will require either increased imports or reduced exports.

\section{FINDINGS}

Increasing import causes a reduction of reserve asset or losing of foreign currency every year which can be used in our country for the manufacturing or production of those items which are being imported from abroad. The reserve could be used for the advancement of country products.

Various sectors like jute, fish, shrimp, leather, ICT are yet to nourish like readymade garment sectors.

An increase in service receipt is an indication that our service providing capacity is improving.

As per primary income is concerned, focus is drawn by the huge difference between receipts and payments.

High imports for construction purposes and natural calamities are an obstacle to trade surplus.

An increasing trend in DFI states that our economy is capable of drawing foreign investment for various development purposes.

There was a fall in remittances in the previous years.

For establishing enterprises, the country is still dependent on imported equipment. 
There was a trade deficit from 2012-13 to 2016-17 showing an import orientation.

\section{RECOMMENDATIONS}

- $\quad$ The export of goods and services should be increased according to government policy in order to bring a positive trade balance which will ultimately lead to a positive current account balance.

- $\quad$ Potential export items should be increased in order to accelerate export earnings.

- Quality of the products should be ensured in order to attract more foreign countries for exporting.

- $\quad$ Attempt should be taken by the concerned authorities to combat future political instability.

- $\quad$ The death of few foreigners and Bangladeshi people in Holey Artisan Bakery in Dhaka is an important reason why foreigners feel unsecured in Bangladesh. So the security should be tightened from the part of the government for the deputized persons and foreigners.

- Infrastructural development, logistical support from port authority and related concern and finally proper management of supply chain should be ensured so that we can easily export goods and services across border.

- Development of relationship with foreign countries so that it may be possible to convince them to take more manpower from our country and at the same time process of exporting manpower should be easedso that we can earn more remittance.

- $\quad$ Hurdles faced by the exporters in the $\mathrm{p}$

- $\quad$ ort while exporting should be mitigated and the overall conditions of our ports should be improved so that smooth delivery is ensured.

- We need to reduce cost of doing business so that potential exporters along with existing exporters will be more enthusiastic in export oriented business.

- $\quad$ Exports should be encouraged by granting various bounties to manufacturers and exporters. At the same time, imports should be discouraged by undertaking import substitution and imposing reasonable tariffs.

- Inflation discourages exports and encourages imports. Therefore, government should square inflation and lower the prices in the country.

- $\quad$ Attention should be given to develop Small Scale Industries along with large and labor intensive Industries to facilitate more export.

- $\quad$ The current government export and import policy emphasizes on more export and less import. Besides this proper timely monitoring and requited modification of export and import policy should be ensured.

- $\quad$ Exports should be encouraged by granting various bounties to manufacturers and exporters. At the same time, imports should be discouraged by undertaking import substitution and imposing reasonable tariffs.

- $\quad$ Restrictions and Import Substitution are other measures of correcting disequilibrium.

- Inflation (continuous rise in prices) discourages exports and encourages imports. Therefore, government 
should check inflation and lower the prices in the country.

Government should control foreign exchange by ordering all exporters to surrender their foreign exchange to the central bank and then ration out among licensed importers.

- Devaluation of domestic currency means fall in the external (exchange) value of domestic currency in terms of a unit of foreign exchange which makes domestic goods cheaper for the foreigners. Devaluation is done by a government order when a country has adopted a fixed exchange rate system. Care should be taken that devaluation should not cause rise in internal price level.

- Like devaluation, depreciation leads to fall in external purchasing power of home currency. Depreciation occurs in a free market system wherein demand for foreign exchange far exceeds the supply of foreign exchange in foreign exchange market of a country (Mind, devaluation is done in fixed exchange rate system.)

- $\quad$ Adoption of a new policy regime aiming at expansion of productive capacities of the country that enhances utilization of productive resources through enhanced entrepreneurial capabilities and increased production linkages may be fruitful in achieving developments in this sector, thereby fostering growth of the economy.

- However, in order to address the current structural bottlenecks that impede developments in the external sector of economy, a thorough re-examination of the current trade and industrial policies is pressing.

\section{CONCLUSIONS}

The balance of payments of Bangladesh is an indicator of what are the inflows and outflows for a particular period. Although the economy observed a comfortable current account balance, the decreasing rate of remittance and manpower exports might cause a serious hamper to the economy by reducing employment opportunities and output levels. One way of looking at a trade deficit is that we're getting richer, we're gaining access to more imports, the very thing we conduct trade for in the first place. Imports are the reason that we trade, exports being just the hard work we've got to do to be able to afford them. Historically, Bangladesh faces trade deficit balances because we have to import various items in order to meet our domestic demand. We are lagging behind in exporting because of our inefficiency in the utilization of our indigenous resources. The poor quality of our products is another reason which retards to compete with foreign competitors. We are gradually improving in international trade, but it is not satisfactory because of our high imports. For now, our current account deficit is not big enough to be too concerned about. There are many economies which run deficits of 2-3 percent of GDP-ours is less than 1 percent. But steps need to be taken to address the slump in exports and remittances, and to stem illicit financial outflows through trade miss-invoicing so that the deficit does not spiral out of control. Some will argue for better administrative and technological capacity to identify such illicit outflows. But perhaps we should think more about incentivizing people to keep their money inside the country by generating more confidence in our economy, institutions and political system.

\section{REFERENCES}

1. Jeff Madura (2007), International Financial Management, 9th Edition, Florida: Atlantic University, pp.22-25.

2. M. S. Rahman Chowdhury (2013), “Bangladesh's Balance of Payments: an Econometric Analysis” the Chittagong University Studies, VOL. I, ISSUE4/ULY, pp-337,338 
3. Mohammad A. Ashraf and Hasanur R. Joarder (2009), "Factors Affecting Volatility of Bangladesh Trade Deficit: An Econometric Analysis” ABAC Journal, Vol. 29, No. 2 pp.24-36

4. Islam, Nurul (2004), "Looking Outward-Bangladesh in the World Economy", the University Press Limited (UPL): Dhaka.

5. Sadrel Reza (1981), “The Export Trade of Bangladesh:” Dhaka: University of Dhaka.

6. Abdur Rahim Harmachi (2017) “Bangladesh's Balance of Payment deficit increases”.

7. A. R. Bhuyan (1982), “Non-Traditional Exports of Bangladesh: Trends, Performance and Prospects" Bureau of Economic Research, University of Dhaka.

8. Wahiduddin Mahmood (1982), "Possibilities of Export-led Growth in Bangladesh”, The Bangladesh Journal of Political Economy, Vol. 6, No. 1

9. Dilip Kumar Roy (1991) “Determinants of Export Performance of Bangladesh”, the Bangladesh Development Studies, BIDS, Vol. 19, No. 4.

10. Nasiruddin Ahmed (2001), "Trade Liberalization in Bangladesh: An Investigation into Trends" The University Press Limited, Dhaka.

11. SharjilHaque (2017), Rising current account deficit: How vulnerable are we?

12. Costas Arkolakis, teaching assistant: YijiaLu, Economics, Yale(January 2011) “The Balance of Payments”

13. Mushfica Akhter(2015)," The Impact of Export and Import on Economic Growth in Bangladesh “Vol. 9 • No. 1,.Retrived from http://bv-f.org/WV-09/06.\%20WV\%20Final.-9.pdf

14. Mohammed Ali Nause Russel, Mizuki Nakama \& Mohammad Solaiman, A Comparative Analysis of Revenue Ecology and Decentralization of Service Delivery of the Local Government in Bangladesh on Asian Perspective, International Journal of Accounting and Financial Management Research (IJAFMR), Volume 5, Issue 4, July - August 2015, pp. 7-18

15. Moniruzzaman (2010), "Long Run Relationship between Export and Import of Bangladesh: Growth Trend, Co-integration and Causality Analysis". Retrieved from http://bea-bd.org/site/images/pdf/076.pdf

16. J. Singh (2014) “Causes and Measures of Disequilibrium (Balance of Payment)". Retrieved from http://www.economicsdiscussion.net/balance-of-payment/causes-and-measures-of-disequilibrium-balance-of-payment/621

17. Subo Mukhter (2013), “Causes of Disequilibrium in the Balance Payments", Retrieved from http://www.economicsdiscussion.net/balance-of-payment/causes-balance-of-payment/4-causes-of-disequilibrium-in-thebalance-payments/10897

18. Meghana S (2014), "Disequilibrium in Balance of Payments: Causes and Implications". Retrieved from http://www.microeconomicsnotes.com/balance-of-payments/disequilibrium-in-balance-of-payments-causes-andimplications $/ 1724$

19. Tim Worstall(March 12, 2017)," Why a trade deficit is no bad thing”. Retrieved from http://www.dhakatribune.com/business/2017/03/12/new-prospects-bangladesh-blue-economy/

20. Annual Data, Bangladesh Bank, Statistics Department (Accessed 2 October, 2017). Retrieved from https://www.bd.org.bd/ecodata/bop.php

21. Bangladesh Economic Update (June 2012), Balance of Payment, Volume 3, No. 6, pp-4, UnnayanOnneshan Dhaka, Bangladesh. Retrieved from: http://www.unnayan.org/reports.

22. "Balance of payment statistics" (Accessed 15 October, 2017).Retrieved from ee.europa.eu/eurostat/statistics- 
explained/index.php/balance of payment Statistics

23. “Bangladesh achieves a $\$ 2$ billion balance of payments surplus in six months" (Accessed 15 October, 2017). Retrieved from https://m.bdnews24.com/en/detail/economy.

24. “Be less suspicious about source of FDI” (Accessed March, 2017). Retrieved from www.thedailystar.net

25. Bangladesh Economic Review (2016), Ministry of Finance (MoF), Dhaka, Bangladesh: Finance Division, Ministry of Finance, Government of Bangladesh.

26. Major Economic Indicators: Monthly Update (August 2017), Bangladesh Bank (Vol 08). Retrieved from https://www.bangladeshtradeportal.gov.bd/kcfinder/upload/files/Major\%20Economic\%20Indicators\%20Monthly\%20Update. $p d f$

27. Balance of Payment deficit increases(February 13, 2017).Retrieved from http://mnabd.com/balance-payment-deficitincreases/ 